\title{
ТРЕТЯ ХВИЛЯ МІЖВОСННОЇ УКРАЇНСЬКОЇ ЕМІГРАЦІї ДО БОЛГАРІї
}

\section{В. М. Власенко}

Власенко В. М. Третя хвиля міжвоснної української еміграції до Болгарії. У роботі йдеться про формування української політичної еміграції в Болгарії у міжвоєнний період, а саме третю, найбільш масову хвилю еміграції у листопаді 1920-1922 рр. Крізь призму документів і матеріалів українських, російських і болгарських архівів та емігрантської преси показані перипетії виходу українців на еміграцію, прибуття та розміщення їх у Болгарії, ставлення місцевої влади до емігрантів та діяльність міжнародних, державних та громадських інституцій з надання допомоги біженцям.

Ключові слова: Болгарія; російська еміграція; українська еміграція; хвиля еміграції.

Власенко В. Н. Третья волна межвоенной украинской эмиграции в Болгарию. В работе речь идет о формировании украинской политической эмиграции в Болгарии в межвоенный период. Рассказывается о третьей волне эмиграции в ноябре 1920-1922 гг. Сквозь призму документов и материалов украинских, российских, болгарских архивов и эмигрантской прессы показаны перипетии эмиграции украинцев, прибытие и размещение их в Болгарии, отношение местной власти к эмигрантам и деятельность международных, государственных и общественных институтов по оказанию помощи беженцам.

Ключевые слова: Болгария; русская эмиграция; украинская эмиграция; волна эмиграции.

Vlasenko V. M. The Third wave of the interwar Ukrainian emigration to Bulgaria. The article describes the formation process of the Ukrainian emigration to Bulgaria during the interwar period. All facts are based on previously unknown documents stored in the central state archives of Ukraine, Russia and Bulgaria. The article provides a thorough introduction to the third wave of the emigration taken place in November 1920-1922. The materials, used in the article, originate from Ukrainian, Russian, Bulgarian emigre press archives, and depict the vicissitudes of Ukrainian emigration, its arrival and living conditions in Bulgaria, as well as the attitude of local authorities to emigrants and steps taken by international, governmental and public institutions in order to assist refugees.

Keywords: Bulgaria; Russian emigration; Ukrainian emigration; wave emigration.

Військово-політичні події 2014-2015 рр. в Криму та на Донбасі призвели до появи в Україні багатотисячної групи тимчасово переселених осіб і біженців. Декілька сотень тисяч наших співвітчизників опинилися поза межами Батьківщини. За останні 100 років Європа взагалі й Україна зокрема неодноразово стикалися із проблемою біженців. Уперше вона стала актуальною майже для всіх країн континенту під час Першої світової війни, вдруге - внаслідок революційних подій 1917-1921рр. в колишній Російській імперії, коли на еміграцію вийшло більше 1 млн осіб, у тому числі декілька сотень тисяч уродженців та жителів України ${ }^{1}$. Переважна більшість із них опинилася в Свропі. Саме тут сформувалися політичні центри еміграції, діяли політичні партії, перебували лідери української політичної еміграції, колишні керівники та члени українських урядів, академіки і професори, генерали й адмірали, церковні та культурні діячі, письменники й митці. Але основну масу емігрантів складали прості люди.

В історичній літературі знайшли відображення різноманітні сторони життєдіяльності української еміграції на рівні континенту, окремих його регіонів та країн. Проте ії існування на Балканах, зокрема в Болгарії, висвітлене недостатньо. Окремі дані про українську еміграцію в цій балканській країні наводяться у монографіях з історії міжвоєнної української політичної еміграції в Європі ${ }^{2}$, українсько-болгарських відносин ${ }^{3}$, військовополонених та інтернованих ${ }^{4}$. Різноманітні аспекти життєдіяльності еміграції показані у численних статтях української наукової періодики. Серед них - початок формування міжвоєнної української політичної еміграції в Болгарії, а саме перша та друга їі хвилі ${ }^{5}$. Проте поза увагою дослідників залишилася третя і наймасовіша хвиля української еміграції до цієї країни. Зауважимо, що у зарубіжній (болгарська, російська, сербська) науковій літературі 3 історії російської еміграції в Болгарії український аспект щодо хвиль еміграції не розкривається ${ }^{6}$ У книзі П. Мангачева про українську еміграцію в Болгарії питання про хвилі еміграції взагалі не порушується .

(C) Власенко, В. М., 2015 
Поняття української політичної еміграції міжвоєнного періоду має подвійний зміст. У широкому сенсі вся міжвоєнна еміграція вважається політичною, оскільки саме політичні причини виходу на еміграцію були визначальними. У вузькому сенсі політична еміграція - частина емігрантського загалу, яка була політично вмотивована, ідеологічно визначена, організаційно структурована та сповідувала ідею відновлення незалежної та суверенної України у різних їі формах. Тому автор ставить собі за мету показати завершальний етап процесу формування міжвоєнної української політичної еміграції в Болгарії, а саме третю iii хвилю. Під хвилями еміграції ми розуміємо повторювані масові еміграційні потоки.

Перша хвиля охоплює період із другої половини 1918 р. і до кінця 1919 р., коли до Болгарії прибули окремі представники заможних верств суспільства, військові та цивільні особи після поразки військ Антанти у квітні 1919 р. (так звана «франиузька» евакуація Одеси). Друга хвиля припала на зиму - весну 1920 р., коли внаслідок низки поразок армії генерала Антона Денікіна з Одеси та Новоросійська були евакуйовані військові та цивільні особи. Після нетривалого перебування в країні біженці або поверталися додому, або реемігрували до країн Центральної та Західної Європи. Внаслідок цього в Болгарії залишилося лише декілька сотень емігрантів. Одночасно здійснювався процес повернення через Болгарію на батьківщину військовополонених колишніх російської й австро-угорської армій.

Третя хвиля розпочалася восени 1920 р. після евакуації «Русской Армии» (РА) генерала Петра Врангеля з Криму. Поряд із військовими батьківщину залишило чимало цивільних осіб. Евакуація, що тривала 313 до 16 листопада 1920 р., здійснювалася з 5 кримських портів: Євпаторії, Керчі, Севастополя, Феодосії та Ялти. Для цього було використано близько 130 російських та іноземних суден, у тому числі військові кораблі, пасажирські пароплави, транспортні та парусні судна, криголами, підводні човни, баржі, буксири та катери ${ }^{8}$. Усі вони прямували до Константинополя. У другій половині листопада 1920 р. ця ескадра стояла вже у бухті Мода в Босфорі. Згодом почали оприлюднювати дані щодо загальної кількості прибулих. Так, за даними Посольства УНР у Константинополі, з Криму до Туреччини прибуло 120 тис. осіб, з яких військових - 70 тис. осіб, серед них українців - 35 тис. осіб, у тому числі 2 тис. повстанців на чолі з отаманами Ангелом, Гелєвим, Олександром Реківим, Уренюком 9 , Чорною Хмарою (Антон Гребенник) ${ }^{10}$, Демидом Гулаєм ${ }^{11}$, Федорченком ${ }^{12}$ та ін. Посольство УНР в Болгарії повідомляло, що з Криму евакуювалося близько 130 тис. осіб ${ }^{13}$, історики еміграції, сучасники тих подій -136 тис. осіб ${ }^{14}$. За даними самого П. Врангеля, до Константинополя прибуло 150 тис. осіб, з яких дві третини становили військові й одну третину - цивільні особи ${ }^{15}$.

Невдовзі після прибуття біженців до Туреччини розпочалося так зване «розвантаження» Константинополя. Інтернованих військових і біженців розмістили в районі Галіполі, Чаталджі, на острові Лемнос. Російська військова ескадра вирушила до французької військової бази Бізерта, звідки поступово емігранти виїжджали до Алжиру, Марокко та країн Європи. Частина біженців самотужки намагалася потрапити до балканських країн. У листі колишнього співробітника Посольства УНР в Софії Федора Шульги до міністра закордонних справ УНР Андрія Ніковського від 29 січня 1921 р. йшлося саме про це: «В Царгороді, на Галіполі, на Лемносі, в Софії, Варні, Бургасі, Білгороді і т. д., і т. д., куди тільки досягають наші біжениі, скрізь нужда, холод, голод, хвороби. Помочі нашим людям, україниям, немає. 3 Царьгородських лагерів, з під опіки франиузів втікають десятки, сотні наших людей без пашпортів і без копійки грошей, без теплої одежі, без хліба і прямують на Північ, сподіваючись там, серед братів славян знайти собі притулок і шматок хліба. Позаяк у більшості з них нема законного (розумій франиузького) пропуску, то на кордонах, особливо в Тракії (греки), їх ловлять, підстрілюють. Декому вдається все ж пробратися через ворожі кордони, а багащько й гине від холоду, голоду $і$ солдатських куль» ${ }^{16}$. Про втечі вояків-українців із таборів у Туреччині та нелегальний перетин ними болгарського кордону повідомляв також і голова Надзвичайної дипломатичної місії УНР в Румунії й одночасно тимчасовий керівник Українського посольства УНР в Болгарії Кость Мацієвич ${ }^{17}$.

Унаслідок припинення фінансування РА уряд Франції сприяв переселенню біженців до Бразилії, Перу, Мадагаскару та вступу військовослужбовців до французького Іноземного легіону.

Частина тільки-но прибулих із Криму біженців була одразу направлена до балканських країн. Переговори П. Врангеля 3 керівниками Болгарії, Греції, Королівства сербів, 
хорватів і словенців та Румунії щодо приймання біженців тривали впродовж листопада 1920 р. Транспортування військових та біженців до Болгарії відбувалося з кінця 1920 р. і до кінця 1922 р. Тиск на уряд Олександра Стамболійського у справі приймання біженців із Росії й України здійснювався різнобічно. 3 одного боку, у листопаді 1920 р. французький уряд наполягав на тому, щоб Болгарія прийняла з Константинополя 10 тис. емігрантів, проте Софія погодилася на приймання лише 3 тис. осіб за умови фінансування Францією витрат на їх утримання. Аргументами болгарської сторони були наявність на її території вже близько 10 тис. біженців із Росії й України та потоки болгарських біженців із Фракії та Македонії. Наприкінці листопада 1920 р. до Бургаса та Варни прибуло 4170 осіб, з яких близько 600 невдовзі реемігрували до інших європейських країн ${ }^{18}$. Секретар Українського посольства у Софії Микола Лаврик повідомляв МЗС УНР, що тоді прибуло 4-5 тис. осіб ${ }^{19}$. Французький уряд пов'язував питання приймання біженців зі справою вступу Болгарії до Ліги Націй. Наприкінці 1920-1921 рр. Франція ще неодноразово пропонувала уряду О. Стамболійського прийняти нові групи російських емігрантів із Туреччини, середземноморських островів та Північної Африки.

З іншого боку, у грудні 1920 р. Раднарком РСФРР і Комінтерн надіслали болгарському уряду ноту протесту у зв'язку з розміщенням на ії̈ території вояків армії П. Врангеля. В ній ішлося й про встановлення «дружніх відносин» із РСФРР, що фактично означало альтернативу вступу Болгарії до Ліги Націй. Уряд О. Стамболійського на це не погодився ${ }^{20}$. Згодом із нотою протесту проти формування на території Болгарії ворожих армій виступив і Уряд УСРР, очолюваний Х. Раковським ${ }^{21}$.

Навесні 1921 р. Франція остаточно припинила фінансування біженців, передавши цю справу Раді російських послів у Парижі та Лізі Націй, які також пропонували Болгарії збільшити контингент біженців на ії території. При цьому окремі представники Ліги Націй пов'язували вирішення цього питання з можливістю перегляду статей Нейїського договору щодо кількості болгарської армії. До них долучилося й Міжнародне товариство Червоного Хреста, яке поставило питання про розміщення на території Болгарії 200 дітей козаків та супроводжуючих їх осіб з о. Лемнос. Уряд Болгарії погодився на це. Врештірешт, після кількамісячних переговорів представників П. Врангеля в Болгарії - Олександра Петряєва та Василя Вязмітінова - 3 болгарськими урядовцями було вирішено питання приймання нових груп емігрантів ${ }^{22}$. До кінця 1922 р. уряд Болгарії неодноразово задовольняв прохання Ліги Націй про приймання російських біженців ${ }^{23}$.

Існують суперечливі дані щодо загальної кількості російських військових у Болгарії. За «Таємною адресною книгою частин Російської армії» від 24 лютого 1922 р. їх було 15129 осіб $^{24}$, за даними Українського посольства у Софії (квітень 1922 р.) - 17 тис. ${ }^{25}$, штабу 1-го Армійського корпусу (травень 1922 р.) - 19 169, Спілки повернення на батьківщину (Совнарод) у квітні 1923 р. - 18728 (4012 козаків, 4042 солдати та 10674 офіцери) $)^{26}$, болгарського історика Д. Даскалова - 19512 осіб, у тому числі 850 жінок і дітей ${ }^{27}$. На думку Ц. Кьосевої, найбільш достовірними є дані першого джерела, оскільки відображали стан армії на момент іiї прибуття до Болгарії. У решті джерел показники свідомо завищені, бо їх укладачі/автори були зацікавлені показати більшу кількість військового контингенту для, з одного боку, отримання допомоги (штаб 1-го армійського корпусу), з іншого - демонстрації масштабів загрози ${ }^{28}$.

Всього ж, за даними Л. Спасова, з листопада 1920 до грудня 1921 р. до Болгарії прибуло 23335 осіб $^{29}$, Ц. Кьосевої - 23145 осіб $^{30}$. У 1922 р., за підрахунками М. Йовановича, Болгарія прийняла з Туреччини, Кіпру та Сгипту ще 6343 особи ${ }^{31}$, Ц. Кьосевої - 6787 осіб. Остання велика група з Туреччини у складі 500 осіб прибула до країни на початку 1928 р. Крім того, у серпні - вересні 1922 р. уряд Болгарії забезпечив безкоштовний проїзд територією країни 7 тис. біженців, які прямували до Чехословаччини ${ }^{32}$.

Загальну кількість емігрантів із Росії й України, які перебували у Болгарії впродовж трьох хвиль еміграції, також важко встановити. Це пояснюється кількома факторами. Поперше, еміграція відзначалася високим рівнем мобільності (динаміки пересування), що ускладнювало іiі підрахунок. По-друге, велика частина емігрантів повернулася на батьківщину (10-12 тис. осіб) $)^{33}$. За радянськими агентурними даними, навесні 1922 р. 3 Константинополя та Болгарії щодня виїжджало 10-15 чоловік ${ }^{34}$. По-третє, в країні не було єдиної системи обліку, тому дані державних інституцій та громадських організацій, що надавали допомогу емігрантам, істотно відрізнялися через бажання показати якомога більші 
масштаби проблеми. Український дипломат Отто Ейхельман стверджував, що на 31 січня 1922 р. у Болгарії перебувало 29933 біженців із Росії й України, в тому числі 25248 чоловіків, 3061 жінка, 1684 дитини ${ }^{35} .1$ лютого 1922 р. Російське товариство Червоного Хреста (стара організація) зареєструвало 31744 біженці, в тому числі 26867 чоловіків, 3171 жінку та 1700 дітей $^{36}$. За даними дипломатичного агента УНР в Болгарії, у квітні 1922 р. в країні перебувало 32 тис. біженців із Росії й України, в тому числі 27 тис. чоловіків та 5 тис. жінок і дітей ${ }^{37}$, за даними голови Української громади в Болгарії полковника Бориса Цибульського, у 1922 р. - близько 30 тис. емігрантів ${ }^{38}$, за даними російського громадськополітичного діяча Павла Мілюкова, - до 35 тис. емігрантів ${ }^{39}$. Сучасні дослідники визначають їх кількість 35-36 тис. осіб ${ }^{40}$. Хоча іноді трапляються й відверто завищені дані. Так, голові Революційної військової ради Республіки Леву Троцькому доповідали, що на початку 1922 р. у Болгарії перебувало 50 тис. російських біженців ${ }^{41}$. На початку 30 -х років ХX ст. МЗС Болгарії інформував Лігу Націй про те, що у 1921-1922 рр. країна прийняла 45 тис. російських біженців ${ }^{42}$. У першому випадку це робилося 3 метою підкреслити масштаби проблеми біженців, у другому - вклад Болгарії в іiї вирішення.

Існують суперечливі дані й щодо кількості українців у складі емігрантського загалу в Болгарії. За даними секретаря Українського посольства у цій країні, на початку 1921 р. «украӥниів військових у Болгарії зараз понад тисячу, але кожного дня приїзять групами й окремо з Царгорода все нові» ${ }^{43}$. Більшість із них бажала виїхати до Польщі, де перебувала інтернована Армія УНР. Наприкінці березня 1921 р. К. Мацієвич повідомив МЗС УНР про те, що серед українських біженців у Болгарії «налічується до 500 повстанців, які евакуювалися разом із Врангелівською армією. Точну регістраџію наших збігиів (біженців - В. В.) ще не переведено, але по ріжним відомостям, правда не перевіреним, можна лічити загальну їх кількість до 2000 чоловік», у тому числі 100-150 осіб - «свідомі, патріоти $і$ діячі наших повстань» ${ }^{44}$. На сторінках української емігрантської преси початку 20 -х років XX ст. наводилися дані про 1200-1500 членів «Української громади в Болгарії» - емігрантської громадської організації з центром у Софії та філіями в регіонах ${ }^{45}$. Генерал Григорій Янушевський у вересні 1921 р. серед російської військової еміграції за політичною орієнтацією виділяв такі категорії: врангелівці - 16 тис. осіб, українці - 1,5 тис., кубанці - 1,5 тис., донці демократичної групи - 500 осіб $^{46}$. На I Конференції української еміграції, що відбулася 1929 р. у Празі, делегат від українських організацій у Болгарії стверджував, що 70\% усієї «емігрантської маси - ие мешканці з території України, Кубані й Дону, так би мовити український етнографічний елемент. На початку еміграції українців, які б свідомо себе виявляли і визнавали за таких, не було більше 2000 душ, серед них, мовляв, інтелігенції украӥнської близько 200» ${ }^{47}$.

У доповідях начальника Генерального штабу до військового міністра УНР від 4 листопада та 20 грудня 1921 р. фігурували дані про перебування в країні від 6 тис. ${ }^{48}$ до 8 тис. українських військових, які жили «своӥм начіональним життям» ${ }^{49}$. Зауважимо, що тут не враховано тих українців, які прибудуть до Болгарії 1922 р. У квітні того ж року дипломатичний агент УНР в Болгарії повідомляв МЗС про те, що з 10 тис. цивільних біженців чоловічої статі російських громадських діячів і чиновників, які орієнтувалися на Врангеля, було близько 2 тис. осіб, донських, кубанських козаків та росіян лівих поглядів, які намагалися жити більш-менш самостійно від Врангеля, - більше 4 тис. осіб, «свідомих» українців, які нічого спільного з Врангелем не хотіли мати й орієнтувалися на Українське посольство, - більше 3 тис. осіб ${ }^{50}$. У сучасних дослідженнях йдеться про 7 тис. українців, які опинилися в Болгарії після поразки національно-визвольної боротьби та закінчення громадянської війни в Росії ${ }^{51}$.

Такі розбіжності кількісних показників пояснюються тим, що у документах йшлося про різні категорії українців, оскільки автори (військові, дипломати, самі емігранти) застосовували різні критерії при визначенні поняття «українець». Найчастіше українців виділяли за географічно-територіальною ознакою, тобто місцем народження або проживання. Більшість армії Врангеля складали мобілізовані молоді люди переважно з Катеринославщини, Полтавщини, Харківщини, Херсонщини, меншу частину - 3 Київщини і Чернігівщини, зовсім мало - 3 Волині та Поділля ${ }^{52}$. Тому за цією ознакою питому вагу українців серед усього російського емігрантського загалу визначали як $70 \%$ і навіть $80 \%$. всі народжені в Україні вважали себе українцями, так само як частина кубанських козаків в еміграції ототожнювала себе більше з Україною, ніж із Росією. 
В умовах екстремального, непевного, складного становища (чим насправді й є еміграція) для багатьох біженців поділ на українців та росіян був умовним і мінливим. Наприклад, колишні професори Новоросійського (Одеського) університету Василь Зав'ялов та Михайло Попруженко спочатку прихильно поставилися до української справи у Болгарії, у 1922 р. були членами Тимчасового комітету Українського товариства Червоного Хреста, але згодом стали її критиками та ворогами ${ }^{54}$. 3 іншого боку, у 1923 р. до правління Української громади в Софії звернулася група юнаків із заявою: «Зібрання школярів Українців російської гімназї̈ прохає вас прийняти всіх нас до складу Украӥнської громади. Нам, иколярам Украӥниям, існувати самітно дуже тяжко, але, покладаючись на Пречисту Матір, гадаємо, що Ви не відштовхнете нас від себе в июю тяжку хвилину і дасте змогу дочекатися тої години, коли ми всі станемо під жовто-блакитний стяг» ${ }^{55}$.

Крім того, чимало українських емігрантів у період національно-визвольної боротьби 1917-1920 рр. служили у різних арміях: гетьманській, УНР, УГА, ЗСПР, РА, Червоній, а також у партизансько-повстанських загонах ${ }^{56}$. Наприклад, після занепаду Української Держави чимало членів уряду Павла Скоропадського, вищих державних чиновників, військових стали на бік державних утворень білої Росії, проте в еміграції багато примусово мобілізованих до армії П. Врангеля українців, особливо з Катеринославщини, Полтавщини та Херсонщини, переходило «до Петлюри» ${ }^{57}$. Отже, в еміграції уродженці України могли прилучитися як до української, так і російської спільноти. Тому при виборі визначальною могла стати як матеріальна сторона (орієнтація на того, хто забезпечить найнеобхіднішим - їжею, ночівлею та ліками), так і національне самоусвідомлення, незважаючи на матеріальну скруту. Так, під час зустрічей з деякими українськими біженцями в Болгарії у К. Мацієвича склалося враження, що довготривале перебування під впливом політичних настроїв стосовно української справи, що панували в Криму, не сприяло вияву ними своєї національної ідентичності. Дехто з них, на його думку, вважав себе українцем доти, поки сподівався мати від цього більше користі, ніж від російського підданства ${ }^{58}$.

Українців розрізняли і за рівнем національної свідомості. Вже тоді з-поміж них виділяли свідомих, малосвідомих, несвідомих і ренегатів або малоросів. При цьому майже усі вони у Болгарії перебували в російському емігрантському середовищі, під впливом російських старшин та численної російської інтелігенції і тому думати про «якусь там Україну» на початку еміграції, як стверджував Василь Филонович, просто не могли. До того ж на емігрантів впливало і русофільство болгар ${ }^{59}$. Дипломатичний агент УНР в Болгарії Василь Драгомирецький поділяв усіх українців на дві групи: «свідомих $i$ maкi, якi сліпо тримаються Врангеля. Перші зовсім відокремилися від армії Врангеля, тримають постійний зв'язок з украӥнським посольством і відносяться негативно до добровольиів. Правда є ще такі, які не зовсім відійшли від Врангеля $і$ тримаються його задля харчів, але кількість їх із кожним днем зменшується. Друга група - «украӥниі за назвою», служать Врангелю може ще й вірніше як великороси. Вони переважно в частині Корніловської, не люблять ніяких політичних балачок, задоволені харчами, вихваляються дисиипліною і дуже підозріло приймають інформацію про Головного Отамана Петлюру i його військо», а далі поглиблює характеристику малоросів: «часом і вони з 'ясовуються перед нами в своїй прихильності, але ие все постійно робиться, при звісних умовах: "без Петлюри», «без самостійности», при признанню «общерусского языка», «единой общчей родиныl» $i m . \partial . »^{60}$.

Традиційним був поділ на військових і цивільних осіб (біженців). Українська еміграція на Балканах взагалі й у Болгарії зокрема на $80-85 \%$ була військовою ${ }^{61}$. Проте і цей поділ умовний, оскільки ще у Туреччині частина військових переходила у цивільний стан, отримуючи статус біженців, а потім уже реемігрувала до інших країн. Іноді біженцями («збігиями») називали весь емігрантський загал, у тому числі військових і цивільних осіб.

У документації українських дипломатичних представництв і Генерального штабу Армії УНР фігурувала категорія українських біженців на Балканах (Туреччина, Болгарія, Греція, КСХС), яких можна було використати для боротьби проти більшовиків. Так, на думку голови Товариства Червоного Хреста при армії Врангеля Доріа-Дернеловича, яку він висловив на початку січня 1921 р. у м. Пашкани (Румунія) референту артилерійської управи Армії УНР підполковнику Володимиру Свободі, у таборах поблизу Константинополя є близько 10 тис. донських козаків та 5 тис. українців і кубанських козаків, які бажають воювати у складі Армії УНР ${ }^{62}$. 
У вересні 1921 р. генерал Г. Янушевський писав про «понад 40000 свідомих украӥнських вояків» у регіоні (Туреччина, Балканські країни, Сгипет та середземноморські острови). Ймовірно, йшлося про уродженців та колишніх жителів України. I, незважаючи на відсутність організаційної структури та брак коштів для транспортування їх до Польщі, де перебували інтерновані частини Армії УНР, лише у Туреччині, на думку генерала, можна було зібрати близько 10 тис. осіб і переправити їх через Балканські країни ${ }^{63}$. Секретар Українського посольства у Болгарії щодо цієї категорії біженців на Балканах писав: «Не тільки україниі, але й инші так чи інакще зв'язані з Україною сподіваються дістатися на Батьківщину тільки під прапором украӥнським, тільки з украӥнською армією» ${ }^{64}$. На це сподівалися й повстанці, які евакуювалися із Криму разом 3 армією П. Врангеля ${ }^{65}$.

Тобто до українських реемігрантів із Балкан до Польщі могли долучатися і росіяни, які хотіли швидше і легше потрапити на Батьківщину, оскільки Польща мала кордон 3 УСРР, або вважали більш реальною боротьбу з більшовиками у складі Армії УНР. Наприкінці січня - на початку лютого 1921 р. В. Драгомирецького відвідало декілька груп донських козаків. Одна 3 них на чолі з в. о. голови Круга Війська Донського Михайлом Гнилорибовим, заявивши, що донські козаки (Донська демократична група в Болгарії В. В.) бажають допомогти українцям у боротьбі проти більшовиків і таким чином повернутися на Дон, виявила бажання розпочати переговори з Урядом УНР. Для цього були обрані уповноважені М. Гнилорибов та Георгій Кременськов, які й повинні були виїхати до Бухареста для переговорів із К. Мацієвичем ${ }^{66}$. За радянськими агентурними даними, влітку 1921 р. у Тарнові представники Уряду УНР і М. Гнилорибов підписали договір про узгодження дій повстанців в Україні, на Кубані та Дону ${ }^{67}$.

Істотне коливання кількості українських біженців у Болгарії у тогочасних джерелах було пов'язане також і з рееміграцією та репатріацією частини з них.

Отже, за вищенаведеними даними, на початку 1920-х pp. із 35-36 тис. емігрантів 3 України та Росії у Болгарії близько 50\% становили уродженці або колишні жителі України. Велика частина 3 них - «малороси». Тих, які визнавали себе українцями, в тому числі й частина кубанців, і жили «своїм національним життям», нараховувалося 9-11 тис. осіб; які сповідували ідею незалежної України - 7-8 тис.; «організованих» українців, тобто об'єднаних в емігрантські громадські організації, - 1,5-2 тис. і «свідомих» (інтелігентних) українців - близько 200 осіб.

Українським аспектом російської еміграції в Болгарії не дуже переймалися міжнародні організації й уряд Болгарії. Зменшити його значущість намагалася верхівка російської еміграції та П. Врангель. Навпаки, Уряд УНР й Українське посольство у Болгарії хотіли його актуалізувати. Спочатку ставлення болгарського уряду до України було невизначеним. Стисло його позицію висловив тогочасний керуючий ${ }^{68}$ МЗС Сімеон Радєв: «Наме положення юридичне в справі Украӥни зараз є досить неясне. В часи Гетьмана Скоропадського ми визнали Україну як самостійну Державу. Після Версальського миру, коли Брест-Литовський договір пав, наме визнання згубило міжнародну основу. Разом з тим і у вас на Україні ситуація стала невиразною. Наше відношення до України було теж невизначене ніяким актом аж до постанови Міністерства Т[е]одорова, в якій воно заявило про відсутність офіиійних відношень до якого будто Уряду України. На иьому трунті стоїмо ми зараз і по нашому міжнародному положенню ми не можемо $з$ нього зійти. Тим більш, щзо тепер, коли вся Україна занята большевиками, а ваш Уряд i армія знаходяться на емігрантському становищу, питання Українське з правно-формального боку являсться дуже трудним $і$ заплутаним» ${ }^{69}$. Проте, за свідченням МЗС УНР, ставлення до українського питання поступово змінювалося під впливом зустрічей прем'єр-міністра Болгарії з головами НДМ УНР у Варшаві та Бухаресті. Саме тоді О. Стамболійський вперше виявив прихильність до УНР і висловив упевненість у тому, що незалежна Україна буде існувати ${ }^{70}$.

Подальше з'ясування обопільних позицій відбулося під час візиту до Болгарії у березні 1921 р. нового керуючого Українським посольством у Софії К. Мацієвича. Перебуваючи у Болгарії 5-11 березня, він вирішив такі головні завдання. По-перше, офіційно представив вірчі грамоти прем'єр-міністру, зустрівся з керуючим МЗС С. Радєвим та познайомився з болгарськими урядовцями; по-друге, з'ясував політичні настрої в Болгарії та серед російської еміграції; по-третє, налагодив роботу Українського посольства; по-четверте, визначив становище української еміграції та засоби його покращання ${ }^{71}$. 
Після від’їзду українського дипломата до Румунії ставлення болгарської влади до українців не змінилося. Вона виявляла до них прихильність, але не підтримувала. Українські біженці користувалися такими самими правами, як і росіяни. Вони мали право вільно перебувати у Болгарії, при знаходженні роботи зверталися до Українського посольства, яке $з$ дозволу влади забезпечувало їх квитками на безкоштовний проїзд залізницею до місця роботи ${ }^{72}$. Посольство намагалося підтримати морально і матеріально українських біженців, здійснювало заходи для відокремлення їх від російського загалу, звертало увагу болгарського суспільства й уряду на небезпеку поневолення українського народу, вказувало на негативні дії Добровольчої армії, проте, на думку В. Драгомирецького, робило це примітивно, за наявності внутрішніх і зовнішніх інтриг, за відсутності інтелігентних, національно свідомих сил та за браком коштів, а тому програвало росіянам у справі впливу на емігрантів ${ }^{73}$.

Загострення суперечностей між болгарським урядом і російським військовим контингентом ${ }^{74}$ у березні 1922 р. та розпочата реєстрація військових колишньої армії Врангеля спричинили занепокоєння серед українських емігрантів. До В. Филоновича й Українського посольства надійшло багато звернень від емігрантів із проханням негайно перевести їх до Армії УНР. Посольство намагалося убезпечити себе й українських емігрантів від звинувачень у підтримці російських військових ${ }^{75}$.

Особливо напруження зросло у зв'язку з мобілізаційними планами П. Врангеля та рішенням Вищої адміністративної ради Міністерства внутрішніх справ і народного здоров'я Болгарії від 26 березня 1922 р., яким передбачалося розформування російської армії та висунення військовим ультиматуму: або працевлаштування в Болгарії, або повернення на батьківщину. Під впливом рішень Генуезької конференції О. Стамболійський видав розпорядження: розпочати розформування російської армії. Одночасно з ініціативи ЦК БКП (т. с.) була створена більшовицька організація «Совнарод», яка і повинна була організувати репатріацію військових і цивільних осіб до радянських Росії й України. В цих умовах Українське посольство подало прем'єр-міністру Болгарії ноту і меморандум, а Міністерству закордонних справ - 4 заяви, в одній з яких заперечувався будь-який зв'язок Уряду УНР із врангелівськими організаціями ${ }^{76}$.

Українсько-російські відносини на початку еміграції були напруженими. На думку В. Драгомирецького, висловлену ним наприкінці 1921 р., як командування російського військового контингенту, так і верхівка донського козацтва, крім Донської демократичної групи, зневажливо ставилися до українських біженців, називаючи їх «мазепиниями». Вони поділяли українців на тих, хто «з ними і під ними», та тих, хто захоплений сепаратизмом. Перших вважали своїми і допомагали нарівні з росіянами, других «відштовхували» від себе, змушуючи голодувати. Представників УНР визнавали лише тоді, коли це було їм потрібно, за інших обставин називали самозванцями і за першої нагоди дискредитували. Особливо яскраво це виявилося у справі допомоги біженцям із боку Російського товариства Червоного Хреста (РТЧХ). Українцям першої категорії ії надавали, «сепаратистам» 3 українськими паспортами, виданими у посольствах УНР у Константинополі та Софії, - ні, відмовляючи в їжі та притулку ${ }^{77}$. Дійшло до того, що на вході до приміщення організації було вивішене оголошення, засвідчене печаткою РТЧХ: «Представительство Российского Общества Красного Креста в Болгарии оказывает помощь только тем из беженцев, которые предъявляют русские документы, удостоверенные Российской Дипломатической Миссией в Софии». Співробітники РТЧХ стверджували, що допомога буде надана за умови обміну українського паспорта на російський. Із цієї причини у допомозі відмовили багатьом українським біженцям, зокрема доньці відомого українського громадського діяча в Криму В. Леонтовича, повстанцям й офіцерам з армії П. Врангеля Н. Палагуті, М. Пухальському, Ю. Бережному, В. Живодару, Балакіну, Печеному, Нуджевському, Морозу, Свірку та іншим ${ }^{78}$.

Про це йдеться також у доповідях В. Филоновича Головному отаману військ УНР 79 , К. Мацієвича ${ }^{80}$, Ф. Шульги ${ }^{81}$ та співробітників Українського посольства в Болгарії Мiністерству закордонних справ УНР. Частина членів РТЧХ була незадоволена таким ставленням до біженців і за підтримки американців й англійців, які фінансували товариство, намагалася знайти порозуміння з Українським посольством. Ще у листопаді 1920 р. американці й англійці запропонували спільне з українською стороною фінансування окремої організації для допомоги українським біженцям. Проте через брак коштів та 
відсутність на той момент ініціативних людей, які б не належали до складу посольства, проект не був реалізований ${ }^{82}$.

За повідомленням генерала Г. Янушевського (під псевдонімом - В. В.) на сторінках газети «Українська трибуна», восени 1921 р. з Галіполі до болгарського міста Сістов прибули штаб і 1-й батальйон 1-ї дивізії РА на чолі з генералом Володимиром Вітковським. Більшість офіцерів та солдатів цього підрозділу склали уродженці Катеринославщини, Полтавщини та Харківщини, мобілізовані свого часу до білої армії. За наказом В. Вітковського підлеглим заборонили спілкуватися українською мовою та вести розмови про С. Петлюру ${ }^{83}$. Таке негативне ставлення до українських емігрантів із боку вищих кіл військової та цивільної російської еміграції, на думку В. Драгомирецького, поступово сприймалося і рядовим складом російських військових. Не поширювалося воно лише серед основної маси цивільних біженців ${ }^{84}$.

Допомогу російським біженцям у Болгарії, як і під час попередніх хвиль еміграції, надавали Верховний комісаріат Ліги Націй з питань біженців і військовополонених при Міжнародному бюро праці та його національний представник у Болгарії єпископ Стефан, Міжнародне, Американське, Болгарське та Російське (с. о.) товариства Червоного Хреста, Комітет допомоги російським емігрантам, Слов'янське товариство в Болгарії, Російськоболгарський благодійний комітет, Всеросійський земський союз, Всеросійський союз міст та інші громадські організації ${ }^{85}$, а для репатріантів - Спілка повернення на Батьківщину та радянські Російське й Українське товариства Червоного Хреста ${ }^{86}$.

Менш потужними були державні та громадські інституції, які надавали допомогу українським біженцям. У зв'язку з тим, що Уряд УНР перебував поза межами Батьківщини і тому не мав достатніх коштів не лише на допомогу біженцям, але й на утримання державного апарату та дипломатичних представництв, кошти виділялися насамперед на акції, які були спрямовані на збільшення та зміцнення війська УНР. Уряд сподівався невдовзі повернутися в Україну. Тому після з'ясування військового потенціалу української еміграції на Балканах взагалі й у Болгарії зокрема та виявлення здібних до організаційної роботи військових кошти були виділені.

Уперше ідею відкриття у Софії філії Українського товариства Червоного Хреста, їдальні та гуртожитку висловив колишній співробітник Українського посольства Ф. Шульга у листі до міністра закордонних справ УНР А. Ніковського у січні 1921 р. ${ }^{87}$ Невдовзі з ініціативи колишнього командира Окремого Сумського куреня 4-го полку січових стрільців Армії УНР полковника В. Филоновича були створені спочатку «Українська громада», а потім товариство «Січ», культурно-освітній гурток ${ }^{88}$ та притулок під назвою «Українська $x a m a »{ }^{89}$. Мешканцям притулку (бідним і хворим) надавалися безкоштовні обіди, ліки, білизна, одяг, взуття, а іноді й гроші. В «Украӥнській хаті» розміщувалися громадські організації та 3 майстерні ${ }^{90}$.

Оскільки біженці перебували у скрутному матеріальному становищі, то грошова допомога надходила від дипломатичних представництв у Болгарії та Румунії, УТЧХ та організації благодійних вечорів, концертів, вистав тощо. Так, у 1921 р. НДМ УНР у Румунії перерахувала тимчасовому комітету УТЧХ у Болгарії на потреби біженців 2,5 тис. леїв ${ }^{91}$. У жовтні того самого року в болгарській столиці відбулися благодійний концерт та опера П'єтро Масканьї «Сільська честь» за участі артистів Народного театру. Кошти від їх проведення пішли на потреби українських біженців ${ }^{92}$.

У серпні 1921 р. В. Филонович прибув до Тарнова, де зустрівся з С. Петлюрою. Були визначені основні завдання діяльності полковника у Болгарії: розклад врангелівської армії, виокремлення 3 неї українського елемента, привернення української еміграції до державної концепції УНР та нейтралізація серед неї шкідливих для державної справи федеративних течій ${ }^{3}$. У зв'язку з підготовкою Армії УНР до Другого зимового походу В. Филоновичу були дані директиви організувати транспортування емігрантів із Болгарії до Румунії у розпорядження Андрія Гулого-Гуленка та підготовку військових кадрів із повстанців та членів товариства «Січ» у Болгарії ${ }^{4}$. Безпосередньо у Тарнові він отримав доручення: взяти участь у Зимовому поході в Україну наприкінці 1921 р., проте через оприлюднення у пресі директором департаменту пропаганди Міністерства преси та пропаганди УНР Є. Іваненком певної інформації цього не відбулося, а організовану ним для походу спеціальну групу у Болгарії розформували ${ }^{95}$. 
У січні 1922 р. В. Филонович повернувся до Болгарії як інструктор з кооперації. Згідно 3 Положенням про інструкторів українських робітничо-кооперативних організацій поза кордоном головним їхнім завданням було згуртування у Болгарії, Румунії, Туреччині, Чехословаччині та Югославії розпорошених українських емігрантів, які підтримують політичну платформу Державного центру УНР (ДЦ УНР). Насправді йшлося про реєстрацію всіх емігрантів, придатних до війська, об'єднання їх під виглядом робітничих кооперативів у єдину потужну організацію з військовим порядком і дисципліною та підпорядкування ії ДЦ УНР. Серед членів робітничих кооперативів передбачалося здійснення національно-освітніх заходів, інформування про суть української державної справи, попередження про ворожу агітацію та провокації. Інструктори підпорядковувалися військовому міністру через начальника Генерального штабу Армії УНР, в окремих країнах - безпосередньо військовому агенту. Тобто В. Филонович підпорядковувався військовому агенту у Константинополі Володимиру Кедровському ${ }^{96}$.

В. Филонович розгорнув широку діяльність у цій галузі. Упродовж 1921-1922 рр. кількість членів Української громади у Софії та регіонах збільшилася з 30 до майже 1500 осіб. До громади долучилися і новоприбулі наприкінці 1922 р. з Сгипту члени Українського гуртка та Товариства імені гетьмана Івана Мазепи. Була створена низка громадських організацій і гуртків українських емігрантів ${ }^{97} .3$ метою узгодження своєї діяльності їх керівники увійшли до складу Об’єднаної ради українських організацій у Софії. Крім громадських організацій, емігрантами опікувався також і Комітет допомоги українським біженцям у Болгарії (іноді його називали Українським громадським комітетом - В. В.) на чолі 3 В. Драгомирецьким. Він був створений за наполяганням та за підтримки К. Мацієвича. Кошти для своєї діяльності комітет отримував переважно від організації благодійних акцій, концертів, вистав, вечірок тощо. Комітет діяв до 1924 р.

Отже, третя хвиля еміграції з Криму до Туреччини виявилася наймасовішою. Далі міграції відбувалися з Туреччини до балканських країн, у тому числі й Болгарії. Здійснювалося це внаслідок тиску країн Антанти, позиції уряду О. Стамболійського та політичного впливу численних російських емігрантів, які оселилися в Болгарії. До Болгарії прибуло декілька десятків тисяч уродженців та колишніх жителів України, а також кубанських козаків, частина з яких ототожнювала себе з Україною. Усі вони належали до різних соціальних груп і відрізнялися рівнем національної свідомості. Згодом частина з них реемігрувала до інших країн або повернулася на Батьківщину. Тi, хто залишився й усвідомив себе українцем, склали основу міжвоєнної української політичної еміграції в Болгарії.

${ }^{1}$ Трощинський В.П. Міжвоєнна українська еміграція в Європі як історичне і соціально-політичне явище. - К.: Інтел, 1994. - С. 14.

${ }^{2}$ Трощинський В.П. Міжвоєнна українська еміграція... - 259 с.; Політична історія України. XX століття: У 6 т. / Редкол.: І.Ф. Курас (голова) та ін. - Т. 5: Українці за межами УРСР (1918-1940) / Керівник тому В.П. Трощинський. - К., 2003. - 720 с.; Піскун В. Політичний вибір української еміграції (20-ті роки ХХ століття). - К.: МП «Леся», 2006. - 672 с.

${ }^{3}$ Павленко В. Українсько-болгарські взаємини 1918-1939 рр. - К., 1995. - 224 с.

${ }^{4}$ Cрібняк I.B. Українці на чужині. Полонені та інтерновані вояки-українці в країнах Центральної та Південно-Східної Європи: становище, організація, культурно-просвітницька діяльність (19191924 pp.). - K., 2000. -280 c.

${ }_{5}^{5}$ Власенко В. Перша хвиля міжвоєнної української політичної еміграції до Болгарії // Българска украинистика: алманах / Софийски университет «Св. Климент Охридски». - София, 2013. - Бр. 3. - С. 172-184; Власенко В. Друга хвиля міжвоєнної української політичної еміграції у Південно-Східній Свропі // Сумська старовина. - 2013. - № 40. - С. 22-35.

6 Даскалов Д. Бялата емиграция в България. - София: Университетско изд-во «Св. Климент Охридски», 1997. - 181 с.; Спасов Л. Врангеловата армия в България 1919-1923. - София: Университетско изд-во «Св. Климент Охридски», 1999. - 244 с.; Бялата емиграция в България. Материали от научна конференция, София, 23 и 24 септември 1999 г. / Институт по история БАН. - София: ИК Гуттенберг, 2001. - 455 с.; Йованович М. Русская эмиграция на Балканах: 1920-1940 / Пер. с сербск. А.Ю. Тимофеева. - М.: Библиотека-фонд «Русское зарубежье»; Русский путь, 2005. - 488 с.; Косик B.И. Софии русский уголок. Очерки со стихами о русских, покинувших Россию после Октябрьской революции 1917 года и последовавшей за ней гражданской войны. - М.: ПРОБЕЛ-2000, 2007. 236 с.; Кёсева Ц. Болгария и русская эмиграция: 1920-1950-е годы / Пер. с болг., науч. ред. Е.В. Михайлова. - М.: Библиотека-фонд «Русское Зарубежье»; Русский путь, 2008. - 312 с. 
${ }^{7}$ Мангачев П. Украинската емиграция в България през периода между двете световни войни (1918-1944 г.). - София: Колбис, 2011. - 321 с.

${ }^{8}$ Більш детально про евакуацію з Криму див.: Карпов Н. Крым - Галлиполи - Балканы. - М.: Русский путь, 2002. - С. 6-20; Авдеев B.A. Изгнание и возвращение. Из истории эвакуации Русской армии генерала П.Н. Врангеля в ноябре 1920 г. из Крыма и возвращения части ее на родину / В.А. Авдеев, В.Г. Краснов // Русский исход. - СПб.: Алетейя, 2004. - С. 245-261; Гутан Н.Р. Записка о состоянии Русской эскадры // Русская колония в Тунисе. 1920-2000: Сборник / Сост. К. В. Махров. - М.: Русский путь, 2008. - С. 71.

${ }^{9}$ Центральний державний архів вищих органів влади та управління України (далі - ЦДАВО), ф. 3696 , оп. 2 , спр. 448 , арк. 7.

${ }^{10}$ Коваль Р.М. Багряні жнива Української революції. - К.: Укр. письменник, 2005. - С. 251-252.

${ }^{11}$ Центральний державний архів громадських об'єднань України (далі - ЦДАГО), ф. 269, оп. 2, спр. 263, арк. 62.

${ }^{12}$ ЦДАВО, ф. 3696, оп. 2, спр. 360, арк. 32-32зв.

${ }^{13}$ Там само, ф. 3696, оп. 2, спр. 308, арк. 66.

${ }_{14}^{14}$ Давати В.Х. Русская армия на чужбине / В.Х. Даватц, Н.Н. Львов. - Белград, 1923. - С. 7.

${ }_{15}$ Врангель П.Н. Воспоминания генерала барона П.Н. Врангеля: в 2 ч. - М.: Терра, 1992. - Ч. 2: Южный фронт (ноябрь 1916 г. - ноябрь 1920 г.): последняя пядь родной земли. - С. 413; Cnacoв Л. Съюзът за завръщане на родината (1922-1923 г.) // Исторически преглед. - 1983. - Кн. 11. - С. 87; Спасов Л. Врангеловата армия в България 1919-1923. - С. 64-65.

${ }^{16}$ ЦДАВО, ф. 3696, оп. 2, спр. 36, арк. 144-144зв.

17 Там само, ф. 3696, оп. 2, спр. 308, арк. 68.

${ }^{18}$ Спасов Л. Врангеловата армия в България 1919-1923. - С. 73.

${ }^{19}$ ЦДАВО, ф. 1429, оп. 2, спр. 109, арк. 30.

${ }^{20}$ Кёсева Ц. Болгария и русская эмиграция: 1920-1950-е годы. - С. 41-42.

${ }^{21}$ Советско-болгарские отношения и связи: документы и материалы. Т. 1: ноябрь 1917 - ноябрь 1944. - М.: Наука, 1976. - С. 154-155; ЦДАГО, ф. 1, оп. 20, спр. 1035, арк. 20.

${ }^{22}$ Кёсева Ц. Болгария и русская эмиграция: 1920-1950-е годы. - С. 45-48.

23 Зауважимо, що Цветана Кьосева виділяє і четверту хвилю російської еміграції, датуючи їі 1922 р. Див.: Кёсева Ц. Болгария и русская эмиграция: 1920-1950-е годы. - С. 19.

${ }^{24}$ Николов Ц. Дейността на БКП в защита на Съветска Русия (1917-1922). - София: Изд-во БКП, 1960. - С. 163; Чернявски Г. Й. Борбата на БКП против врангелисткия заговор / Г. Й. Чернявски, Д. Даскалов. - София: Изд-во на БКП, 1964. - С. 37; Спасов Л. Врангеловата армия в България 1919-1923. - С. 99-102.

${ }^{25}$ ЦДАВО, ф. 1429, оп. 2, спр. 153, арк. 2.

${ }^{26}$ Кёсева Ц. Болгария и русская эмиграция: 1920-1950-е годы. - С. 50.

27 Даскалов Д. Бялата емиграция в България. - С. 22.

${ }^{28}$ Кёсева Ц. Болгария и русская эмиграция: 1920-1950-е годы. - С. 50.

${ }^{29}$ Спасов Л. Съюзът за завръщане на родината (1922-1923 г.). - С. 87.

${ }^{30}$ Підраховано за: Кёсева Ц. Болгария и русская эмиграция: 1920-1950-е годы. - С. 40-49.

31 Йованович М. Обзор переселения русских беженцев на Балканы // Русский исход. - СПб.: Алетейя, 2004. - С. 182-183.

${ }^{32}$ Кёсева Ц. Болгария и русская эмиграция: 1920-1950-е годы. - С. 53-56.

33 Чернявський Г.Й. Крах змови російських білогвардійців у Болгарії // Український історичний журнал. - 1975. - № 6. - С. 87 (майже 12 тис. осіб); Карпов Н. Крым - Галлиполи - Балканы. - М.: Русский путь, 2002. - С. 129 (більше 11 тис. осіб, серед них - 10\% козакиів, солдатів та офіцерів).

${ }_{34}$ Русская военная эмиграция 20-40-х годов. Документы и материалы. - Т. 1: Так начиналось изгнанье: 1920-1922 гг. - Кн. 2: На чужбине. - М.: Изд-во «Гея», 1998. - С. 227.

${ }^{35}$ Там само. - С. 603.

${ }^{36}$ Даскалов Д. Бялата емиграция в България. - С. 24.

${ }^{37}$ ЦДАВО, ф. 1429, оп. 2, спр. 153, арк. 2.

38 Українська політична еміграція 1919-1945: Документи і матеріали. - К.: Парламентське видво, 2008. - С. 354.

${ }^{39}$ Шкаренков Л.К. Агония белой эмиграции. - М.: Мысль, 1986. - С. 25.

40 Чернявски Г. Й. Борбата на БКП против врангелисткия заговор. - С. 37; Даскалов Д. Бялата емиграция в България. - С. 59; Йованович М. Обзор переселения русских беженцев на Балканы. С. 189; Кёсева Ц. Болгария и русская эмиграция: 1920-1950-е годы. - С. 19.

${ }^{41}$ Васильева Н. Особенности советско-болгарских политико-военных отношений в 20-е годы / Н. Васильева, С. Лавренов // Българо-съветски политически и военни отношения (1917-1941): статии и документи. - София: Изд-во «Св. Георги Победоносец», 1998. - С. 46.

42 Кёсева Ц. Болгария и русская эмиграция: 1920-1950-е годы. - С. 56.

${ }^{43}$ ЦДАВО, ф. 3696, оп. 2, спр. 308, арк. 69; спр. 360, арк. 10, 17.

44 Там само, ф. 3696, оп. 2, спр. 308, арк. 55зв-56. 
45 Українська еміграція в Болгарії // Трибуна України. - Варшава, 1923. - Ч. 2-3. - С. 114; ЦДАГО, ф. 269, оп. 2, спр. 261, арк. 87.

${ }^{46}$ ГАРФ, ф. Р-7440, оп. 1, д. 30, л. 18. При цьому автор стверджує, що більшість військових «тримається врангелівської організації тільки тому, щзо остання щзе більш-менш забезпечує їх грішми».

47 Українська політична еміграція 1919-1945: Документи і матеріали. - С. 355.

${ }^{48}$ ЦДАВО, ф. 1075, оп. 2, спр. 476, арк. 234зв; ф. 1078, оп. 2, спр. 210, арк. 4зв; Срібняк I. Початки української військової еміграції на Балканах (1921-1923рр.) // Військово-історичний альманах. - К., 2006. - № 2. - С. 48.

${ }^{49}$ ЦДАГО, ф. 1, оп. 20, спр. 1311, арк. 29; Павленко В. Українсько-болгарські взаємини 19181939 pp. - C. 167.

${ }^{50}$ ЦДАВО, ф. 1429, оп. 2, спр. 153, арк. 2.

51 Україна крізь віки: в 15 т. - Т. 15: Українці в світі / В.П. Трощинський, А.А. Шевченко. - К.: Альтернативи, 1999. - С. 180.

${ }_{52}$ ЦДАВО, ф. 3696, оп. 2, спр. 308, арк. 107.

${ }^{53}$ ЦДАГО, ф. 269, оп. 2, спр. 282, арк. 212.

${ }^{54}$ Централен държавен архив на Република България (далі - ЦДАБ), ф. 1717К, оп. 1, а.е. 415, л. 1-2; Мангачев П. Украинската емиграция в България през периода между двете световни войни (1918-1944 г.). - С. 34.

55 Українська еміграція в Болгарії. - С. 114-115.

56 Див.: Тинченко Я. Офіцерський корпус Армії Української Народної Республіки (1917-1921): біогр. довідник. - Кн. 1. - К.: Темпора, 2007. - 536 с.; Кн. 2. - К.: Темпора, 2011. - С. 60, 63.

${ }^{57}$ ЦДАВО, ф. 4, оп. 1, спр. 567, арк. 3зв.

58 Там само, ф. 3696 , оп. 2, спр. 308, арк. 56.

${ }^{59}$ ЦДАГО, ф. 269, оп. 2, спр. 282, арк. 212.

${ }^{60}$ ЦДАВО, ф. 3696, оп. 2, спр. 308, арк. 1033в-104, 108.

${ }^{61}$ ЦДАГО, ф. 269, оп. 2, спр. 282, арк. 212.

${ }^{62}$ ЦДАВО, ф. 1075, оп. 2, спр. 203, арк. 39.

${ }^{63}$ ГАРФ, ф. Р-9145, оп. 1, д. 324, л. 16-17. Всього ж у Туреччині на той час було близько 30 тис. українців. Див.: Дашкевич Я. Українська присутність в Туреччині: традиції та сучасність // Друга міжнар. наук.-практ. конф. «Діаспора як чинник утвердження держави Україна у міжнародній спільноті. Українська діаспора у світовій цивілізації» (у рамках Конгресу української діаспори): Зб. доповідей. 18-20 червня 2008 р., м. Львів. - Львів, 2008. - С. 114.

${ }^{64}$ ЦДАВО, ф. 3696, оп. 2, спр. 308, арк. 68.

${ }^{65}$ ЦДАБ, ф. 1717 К, оп. 1, а. е. 397, л. 1-1об.

${ }^{66}$ ЦДАВО, ф. 1429, оп. 2, спр. 28, арк. 46.

67 Там само, ф. 4, оп. 1, спр. 567, арк. 3зв.

${ }^{68}$ Прем’єр-міністр О. Стамболійський одночасно був і міністром закордонних справ.

${ }^{69}$ ЦДАВО, ф. 3696, оп. 2, спр. 308, арк. 113-113зв.

70 Там само, ф. 3696, оп. 2, спр. 278, арк. 169; спр. 404, арк. 187. Більш детально про зустріч О. Стамболійського з головою НДМ УНР у Варшаві Леонідом Михайловим 31 грудня 1920 р. див.: ЦДАВО, ф. 3696, оп. 2, спр. 354, арк. 2-4.

${ }^{71}$ Більш детально про перебування К. Мацієвича в Болгарії див.: Власенко В.M. Візит Костя Мацієвича до Болгарії навесні 1921 р. // Суспільно-політичні процеси на українських землях: історія, проблеми, перспективи: збірник матеріалів III Всеукр. науково-практ. конф., м. Суми, 17 квітня 2015 р.: у 2-х ч. - Суми: Вид-во СумДУ, 2015. - Ч. 1. - С. 3-7.

${ }^{72}$ ЦДАВО, ф. 3696, оп. 2., спр. 308, арк. 56, 66.

73 Там само, ф. 3696, оп. 2, спр. 308, арк. 1013 в.

74 Більш докладно про це див.: Кёсева Ц. Болгария и русская эмиграция: 1920-1950-е годы. C. $57-83$

${ }^{75}$ ЦДАВО, ф. 1075, оп. 2, спр. 827, арк. 333зв.

76 Там само, ф. 3696, оп. 2, спр. 82, арк. 43.

77 Там само, ф. 3696, оп. 2, спр. 308, арк. 103.

78 Там само, ф. 3696, оп. 2, спр. 360, арк. 203в-21.

${ }^{79}$ ЦДАБ, ф. 1717 К, оп. 1, а.е. 373, л. 1; а.е. 378, л. 2; Власенко В. До громадсько-політичної діяльності Василя Филоновича у Болгарії у 1921-1922 рр. // Київська старовина. - 2010. - № 6. - С. 102.

${ }^{80}$ ЦДАВО, ф. 3696, оп. 2, спр. 308, арк. 54.

81 Там само, ф. 3696, оп. 2, спр. 32, арк. 144зв.

${ }^{82}$ Там само, ф. 3696, оп. 2, спр. 308, арк. 67; спр. 360, арк. 20зв-21.

${ }^{83}$ Реянський $\Gamma$. В Болгарії // Українська трибуна. - Варшава, 1922. - Ч. 13. - С. 2.

${ }^{84}$ ЦДАВО, ф. 3696, оп. 2, спр. 308, арк. 103-103зв; С. Л. Врангелівці на Балканах // Українська трибуна. - Варшава, 1922. - Ч. 23. - С. 2-3.

85 Детально про це див.: Даскалов Д. Бялата емиграция в България. - С. 24-33; Кёсева Ц. Болгария и русская эмиграция: 1920-1950-е годы. - С. 51-55. 
${ }^{86}$ Більш детально про це див.: Панайотов П. Руските емигранти в България и движението сред тях за връщане в Съветска Русия (1920-1923 г.) // Исторически преглед. - 1963. - Кн. 5. - С. 34-61; Советско-болгарские отношения и связи: документы и материалы. - Т. 1: ноябрь 1917 - ноябрь 1944. - М.: Наука, 1976. - С. 132-133, 169-170; Спасов Л. Съюзът за заврьщане на родината (1922-1923 г.). - C. 87-99.

${ }^{87}$ ЦДАВО, ф. 3696, оп. 2, спр. 32, арк. 144зв-145.

${ }^{88}$ ЦДАБ, ф. 1717К, оп. 1, а. е. 373, л. 1-2зв; Власенко В. До громадсько-політичної діяльності Василя Филоновича у Болгарії у 1921-1922 рр. - С. 102-105.

${ }^{89}$ ЦДАГО, ф. 1, оп. 20, спр. 1311, арк. 29; ф. 269, оп. 2, спр. 277, арк. 97-97зв.

${ }^{90}$ ЦДАВО, ф. 3696, оп. 2, спр. 308, арк. 107 зв, 154зв; Українська еміграція в Болгарії. - С. 115.

${ }^{91}$ ЦДАВО, ф. 3696, оп. 2, спр. 259, арк. 151-152.

92 Павленко В. Дипломатична місія Української Народної Республіки (1918-1920рр.) // Український історичний журнал. - 1992. - № 12. - С. 28.

${ }_{93}$ Симон Петлюра та його родина. До 70-річчя його трагічної загибелі: Документи і матеріали. - К.: Рада, 1996. - С. 71.

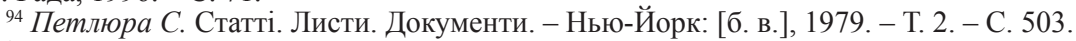

${ }^{95}$ ЦДАВО, ф. 5235, оп. 1, спр. 1518, арк. 52зв; Власенко В.М. «Не може бути українцем той, хто не самостійник» (тема малої батьківщини в листуванні В. Филоновича із земляками) // Сумський історико-архівний журнал. - Суми, 2012. - № XVI-XVII. - С. 41.

${ }_{96}$ ЦДАВО, ф. 1075, оп. 2, спр. 827, арк. 109; ф. 3696, оп. 2, спр. 500, арк. 168-169.

${ }^{97}$ Українська еміграція в Болгарії. - С. 114. 